\title{
Evoluční etika Franse de Waala a její filozofické reflexe
}

\section{Evolutionary ethics by Frans de Waal and its philosophical reflections}

\author{
Filip Jaroš \& Adéla Šrůtková \\ Filozofická fakulta \\ Univerzita Hradec Králové \\ Rokitanského 62, 50003 Hradec Králové \\ filip.jaros@uhk.cz \\ adela.srutkova@uhk.cz
}

\begin{abstract}
Abstrakt/Abstract
Článek představuje teorii původu lidské morálky od Franse de Waala a zhodnocuje přínos filozofických komentářů od Christine M. Korsgaardové a Mary Midgleyové z hlediska oboru evoluční etiky. Základní struktura de Waalova přístupu je v souladu se sentimentalistickou teorií morálky, která určuje soucítění jako bazální morální cit. V interpretaci vlivné neodarwinistické genocentrické školy dále hraje zásadní roli altruismus. Stoupenci tohoto směru (R. Dawkins, G. C. Williams) nicméně obhajují rozdělení krutého světa přírody a etického světa lidské kultury; distinkce byla Fransem de Waalem nazvána „teorií pozlátka“, nebot' vyvolává obraz tenké vrstvy morálky nanesené na sobecké jádro lidské biologické přirozenosti. C. M. Korsgaardová využívá kantovskou etiku, aby ukázala, že zvírata nemohou být počítána za morální, nebot' postrádají schopnost normativní autonomie. M. Midgleyová oponuje jak neodarwinistickému, tak kantovskému rozvrhu etiky a ukazuje, že soucítění patří k přirozenosti společensky žijících druhů a že reflektivní uvažování se vztahuje pouze k nejvyššímu patru evoluce morálky. Pozice M. Midgleyové je pro evoluční zkoumání morálky přínosnější než postup C. M. Korsgaardové.
\end{abstract}

This article introduces Frans de Waal's theory of the origins of human morality and evaluates the merits of the philosophical commentaries of Christine M. Korsgaard and Mary Midgley, and their application to the discipline of evolutionary ethics. The fundamental structure of de Wall's approach is congruent with the sentimentalist theory of morality which determines sympathy as the most vital moral sentiment. A crucial role is also assigned to altruism in the view of morality in the influential genocentric neoDarwinian school. However, proponents of this school (R. Dawkins, G. C. Williams) advocate the separation of the cruel world of nature and the ethical world of humane culture; this is dubbed "Veneer Theory" by F. de Waal, since it invokes an image of a thin layer of morality applied to a selfish core of biological human nature. C. M. Korsgaard applies Kantian ethics to argue that animals cannot count as moral because they are not capable of normative self-government. M. Midgley opposes both neo-Darwinism and the Kantian tradition in ethics in arguing that sympathy is a part of any social species' nature, and that reflective reasoning refers only to the highest peak of moral evolution. It is argued that the position of M. Midgley is ultimately a more fruitful approach to the evolutionary examination of ethics than that proposed by C. M. Korsgaard. 


\section{Úvod}

Evoluční etika je deskriptivním oborem etiky, který je vystavěn na převážně biologických poznatcích o člověku a jeho zvírrecích příbuzných. Předpokladem evoluční etiky je přesvědčení, že lidská morálka vznikla v průběhu evoluce přirozeným způsobem z behaviorálních, mentálních a kognitivních kapacit našich předků mezi primáty. Z logiky biologické evoluce vyplývá, že systém analogický (resp. homologický v biologické terminologii) k lidské morálce se nejspíše vyskytuje u našich nejbližších prríbuzných, šimpanzů a dalších v současnosti žijících lidoopů.

$\mathrm{Na}$ prvním místě je důležité stanovit, co se v oboru evoluční etiky nazývá morálkou. ${ }^{1}$ Mary Midgleyová, podporující evoluční stanovisko př́istupu k etice, morálkou nazývá „ochotu a schopnost hledat společná řešení“ konfliktů. ${ }^{2}$ Holandský primatolog a kognitivní etolog Frans de Waal, v současnosti patrně nejznámější evoluční etik, ve svém díle nevychází z jedné určité definice morálky, což má své dobré důvody. ${ }^{3}$ Morální systém je podle něj emergentní struktura, která vznikla interakcí tendence k prosazování vlastních zájmů a sklonu ke sledování zájmů společných pro skupinu. ${ }^{4}$ Ke vzniku této struktury je přitom potřebná celá řada vlastností a schopností, které budou podrobněji popsány níže. Co se týče vymezení morálky v případě člověka, de Waal uvádí, že „lidská mravnost může být chápána jako ohled na komunitu (community concern) převedený do velmi explicitní formy“. ${ }^{5}$ Jiným přiblížením pojmu morálky je ,smysl pro dobro a zlo (sense of right and wrong), které vzniká ze skupinových systémů řízení konfliktů založených na sdílených hodnotách“. Morálka má v tomto pojetí blízko k pro-sociálnímu chování, i když nalezneme př́klady chování obnovujícího sociální vztahy, které bychom nenazvali morálním. ${ }^{6}$

Komplexnější přehled o tom, co holandský primatolog morálkou myslí, získáme až popisem jeho teorie o vzniku morálky. Zde se odráží výsostně empirický základ jeho badatelské práce, který před analýzou pojmů dává přednost př́íkladům a analogiím mezi sociálními situacemi ve světě zvírrat a lidí. Uvědomme si rovněž, že neostrá definice konceptu morálky odráží anti-esencialistickou povahu Darwinovy evoluční teorie, která

\footnotetext{
${ }^{1}$ Vzhledem $\mathrm{k}$ tematickému zaměření této statě nebudeme rozlišovat mezi morálkou, mravností a etikou. Na tomto místě je také třeba dopředu zdůraznit, že de Waal ani jiní evoluční etikové netvrdí, že zviŕata jsou morálními bytostmi. Budeme se ptát na evoluční základy sociálního chování, jehož speciálně vyvinutá podoba se u lidského druhu explicitně nazývá morálkou.

${ }^{2}$ Midgley (1991, s. 12).

${ }^{3}$ Problematičnost úzké definice morálky pro uvažování v evoluční etice bude ukázána v závěru zhodnocením kritiky C. M. Korsgaardové.

${ }^{4}$ Flack \& de Waal (2000a, s. 19).

${ }^{5}$ de Waal (2006a, s. 252).

${ }^{6}$ Flack \& de Waal (2000b, s. 69).
} 
je základem prŕístupu evoluční etiky. Příliš široká definice morálky může zahrnovat celou škálu sociálních systémů, které budou mít málo společného s lidským chápáním dobra a zla. Na druhé straně, úzce pojaté vymezení mravnosti z našich úvah apriorně vyloučí všechny mimolidské organismy. Jestliže vycházíme z intuice, že lidská morálka ve svých specifických rysech přesahuje sociální systémy známé u zvírat, zároveň však vyrůstá ze společných evolučních kořenů, bude každé její vymezení plodné natolik, nakolik umožní hledání podobností a rozdílů na pozadí popisu sociálního chování blízce př́buzných tvorů.

Takto charakterizovaný program evoluční etiky však vyvolává silný protiproud, zejména mezi morálními filosofy. V našem příspěvku zmíníme kritický pohled americké filosofky Christine M. Korsgaardové, která se zabývá zdroji normativity v lidské společnosti a konstitucí osobní identity. Korsgaardová je přesvědčenou stoupenkyní deontologické tradice etiky, avšak souhlasí s obecným postulátem evoluční etiky v tom smyslu, že lidská morálka je evolučně odvozena od behaviorálních a kognitivních schopností našich zvířecích předků. Zároveň však vystupuje proti takovému přístupu evoluční etiky, který hledá zdroje morálky v altruismu. Zdrojem možnosti morálního chování je normativní autonomie (normative self-government), které bylo dosaženo až na úrovni lidského druhu. Podle Korsgaardové tak spojení zviŕrecího chování s termínem morálky postrádá smysl.

\section{De Waalova teorie o původu lidské morálky}

Frans de Waal je v souladu s většinou evolučních biologů přesvědčen, že základem lidské morálky je altruismus. Na rozdíl od hlavního proudu neodarwinismu však altruismus pojímá primárně z hlediska motivace, ne jako výsledek behaviorálního aktu. Podmínkou altruistického chování je schopnost vcítění se do situace druhého aktéra neboli empatie (empathy). Empatie je předjazyková forma spojení mezi jednotlivci, která teprve sekundárně spadá pod vliv jazyka a kultury. ${ }^{7}$ V souladu s evolučním chápáním vývoje morálky de Waal dokládá existenci empatie již u zviŕat a rozlišuje několik jejích stupňů.

Fylogeneticky nejstarší vrstvou empatie je emocionální nákaza (emotional contagion). Jedná se o automatické zaktivování emocí, které zrcadlí shodnou emoci u

\footnotetext{
${ }^{7}$ Viz de Waal (2006b, s. 24). K rozdílu mezi termíny soucítění a empatie poznamenejme, že ještě Darwin používá pouze termín soucítění (sympathy). Empatie (empathy) se do anglického slovníku dostává až na zač. 20. st. jako překlad německého Einfühlung. De Waal ve zde citovaných dílech soucítění odvozuje od schopnosti empatie, přičemž soucítění je spojeno s altruistickým zájmem o druhého aktéra. Empatie samotná informuje o stavu druhého, ale může vést $\mathrm{k}$ sobeckému jednání. Empatie je tedy nutnou, ale nikoliv postačující podmínkou pro schopnost soucítění. Viz též de Waal (2011).
} 
druhého jedince. Když se staneme svědkem zranění druhého člověka, jsme zasaženi jeho bolestí i přesto, že naši tělesnou integritu nic nenarušilo. Proces je většinou nevědomého charakteru, spouští se i v situacích, kdy stav „emocionálně nakaženého“ není jemu samému na úrovni rozumové reflexe znám. Př́íkladem emocionální nákazy může být nakažlivost smíchu. ${ }^{8}$ Emocionální prožitky jsou napojeny na somatické stavy a mají své neurální koreláty.

Zatímco emocionální nákaza se vyskytuje u všech primátů, další stupeň empatie, nazvaný kognitivní empatie (cognitive empathy), je dobře vyvinutý až u lidoopů. ${ }^{9}$ Podstatou kognitivní empatie je schopnost zhodnotit situaci druhého, pochopit okolnosti podstatné pro emoce, které cítí. Oproti prosté emocionální nákaze se zde aktivuje kognitivní složka, která umožňuje rozlišit emocionální stav druhého od svého vlastního. Touto distancí a pochopením situace druhého je možná cílená pomoc (targeted helping), akt, který má za cíl uvolnit př́ijemce pomoci ze stresové situace. Typickým př́ikladem je šimpanzí mládě, které vylezlo na strom, bojí se pohnout a vydává poplašené zvuky. Matka k němu doběhne a pomůže mu slézt dolů. De Waal upozorňuje, že cílenou pomoc není možno chápat jako snahu usilující o uvolnění primárně vlastního napětí indukovaného stresovou situací. $V$ takovém případě by totiž matce stačilo vzdálit se dostatečně daleko na to, aby mládě neslyšela.

Schopnost empatie je klíčová pro altruistické akty v situacích, které volají po okamžité reakci. Sociálně žijící zvírata se však v souvislosti s dělením potravy či řešením konfliktů nacházejí v časově neohraničeném rámci, ve kterém se role poskytovatele a př́jemce pomoci může opakovaně měnit. Altruistické akty je pak třeba hodnotit v širší perspektivě: důležitým ohledem sociálních interakcí je skutečnost, zda $\mathrm{v}$ průběhu času dochází $\mathrm{k}$ reciprocitě. Trivers ve své teorii recipročního altruismu uvádí, že schopnost opětování pomoci po časové prodlevě je důležitým bodem v evoluci morálky. ${ }^{10}$

Reciproční altruismus může v zásadě nabývat dvou forem. Typickými sociálními interakcemi mezi primáty je vzájemná péče o srst a dělení potravy. Je přirozené předpokládat, že $\mathrm{v}$ rámci dyadických interakcí mají $\mathrm{k}$ sobě někteří jedinci blíže, což se projevuje např. častou vzájemnou péčí o srst. Taková dvojice má zároveň více př́ležitostí k dělení se o potravu. Jde o symetrický vztah, který je založen na pozitivní emocionální vazbě a nevyžaduje používání vyšších kognitivních procesů.

Druhá forma recipročního altruismu je spojena se schopností kalkulace (calculated reciprocity). Zde se již bere ohled na skutečnost, že ve skupině se vyskytuje

\footnotetext{
${ }^{8}$ Provine (2000).

${ }^{9}$ De Waal (2006b, s. 40).

${ }^{10}$ Viz Trivers (1971, s. 35-57).
} 
více individuí a např. rozdělení se o potravu souvisí s očekáváním reciproční pomoci v budoucnosti (může jít o utvoření koalice v případě konfliktu s třetí stranou). Dále zde může hrát roli negativní zkušenost $\mathrm{s}$ jedinci, kteří v minulosti byli při dělení potravy skoupí. Musíme zde předpokládat mentální schopnosti, které k různým jedincům přiřazují různá „ohodnocení“. Nejpřirozenější je předpoklad, že vyšší primáti disponují schopností pamatovat si předchozí altruistické chování jednotlivých zvíratat. ${ }^{11}$ Schopnost reciproční kalkulace byla prokázána u samic malp hnědých a šimpanzů. ${ }^{12}$

Dosud jsme se zabývali emocionálními fenomény odvozenými od interakce dvou jedinců. V některých situacích je však daným chováním ovlivněna skupina jako celek. Jestliže se jedno či více zvîrrat výrazně odchýlí od sdíleného sociálního pravidla (normy chování), je pro skupinu důležité, aby existoval způsob, jak obnovit pořádek, kterým se skupina řídí. Další stupeň morálky je tedy spojen s př́itomností společenského tlaku (social pressure). De Waal uvádí následující př́iklad, kdy neukázněné chování dvou mladých šimpanzích samiček přivodilo skupinovou odvetu:

„Jednoho vlahého večera volal ošetřovatel v arnhemské zoo šimpanze dovnitř, ale dvě dospívající samice odmítaly vstoupit do budovy. Pravidlem v arnhemské kolonii bylo, že žádný šimpanz nedostane krmení, dokud všichni nepřijdou do noční ubikace. Sami šimpanzi toto pravidlo aktivně pomáhali uplatňovat: $\mathrm{k}$ pozdě př́chozím byla hladová kolonie velmi nepřátelská.

Když konečně svéhlavé samičky po více než dvou hodinách přišly, byla jim přidělena zvláštní kóje, aby se předešlo příliš tvrdé odvetě. To je ochránilo jenom na čas. Přriští ráno, když se všichni setkali na ostrově sloužícím jako venkovní výběh, si celá kolonie vybila svou zlobu za opožděnou večeři hromadným pronásledováním, které skončilo pro obě provinilé důkladnou nakládačkou. Není ani třeba podotýkat, že ten večer přišly dovnitř jako první.“13

V této souvislosti můžeme mluvit o fenoménu altruistického trestání: jedná se o chování agresivního charakteru, které je však provedeno s ohledem na skupinový zájem. $\mathrm{V}$ případě dyadických vztahů Trivers hovoří o moralistické agresi, jejímž cílem je obnovení sociálního kódu o poskytování reciproční pomoci. ${ }^{14}$

\footnotetext{
${ }^{11} \mathrm{~V}$ této souvislosti poznamenejme, že důležitou roli paměti pro evoluci morálky rozpoznal již Darwin (komentár k Darwinovi níže).

${ }^{12}$ Flack \& de Waal (2000a, s. 6).

${ }^{13}$ De Waal (2006a, s. 111).

${ }^{14}$ Viz Trivers (1971, s. 35-57).
} 
Ve většině případů je však agresivní chování hrozbou pro sociální kohezi v rámci dané skupiny. Bazálním stavem pro jakoukoliv primátí tlupu jsou afiliativní vztahy v rámci daného hierarchického řádu, nikoliv agonistická konfrontace. Dokonce i tlupa makaka jávského, druhu opice s agresivní pověstí, tráví zhruba $95 \%$ času v poklidném soužití. ${ }^{15}$

Při sporu dvou lidoopů obvykle dochází k jejich následnému usmíření (reconciliation). Jedna strana se přiblíží ke druhé a smíŕlivými gesty (u šimpanze může být doprovázeno mírnými chrčivými zvuky) se dožaduje obnovení vztahu. Někdy je usmíření následující po konfliktu dvou jedinců zprostředkováno třetí stranou (dále píšeme o zprostř̌edkování, angl. mediation). Jako příklad uved'me zajímavý usmiřovací rituál, ke kterému někdy dochází po sporu mezi dvěma dospělými samci šimpanze. Dospělá samice políbí jednoho ze soků a pomalu kráčí k druhému soupeři. První samec ji následuje v těsném závěsu, přičemž se vyhýbá pohledu druhého samce. Samice se posadí do blízkosti druhého samce, první se posadí vedle ní, přičemž ji oba začnou drbat. Za chvíli se samice zdvihne a odejde, samci však jednoduše pokračují ve vzájemném drbání. ${ }^{16}$

De Waal a van Roosmalen jsou autory termínu utěšující chování (consolation behaviour). ${ }^{17}$ Toto chování se vyskytuje po konfliktu dvou jedinců, kdy je poražený aktér utěšován třetí stranou. V mnoha případech jde o aktivní utěšování: přihlížející se k poníženému jedinci bez vyzvání přiblíží a utěšuje ho skrze probírání srsti nebo obejmutí. De Waal uvádí, že zatímco v případě dyadického usmiřování lze vystopovat vlastní zájem aktéra v podobě udržení smírného vztahu, v př́ípadě utěšujícího chování je užitek vlastního angažmá nejasný. Utěšovaný by se dříve či později uklidnil sám a utěšující by se vyhnul nepř́ijemné situaci jednoduše tím, že by si scény nevšímal. Utěšující rituál je tak speciálním případem kognitivní empatie a mezi primáty se prokazatelně nachází jen u lidoopů. ${ }^{18}$

Zajímavým případem, kdy se ke konfliktu dvou či více jedinců přidává třetí strana za účelem jeho ukončení, je „vměšování se do konfliktu“ (dále jen vměšování, angl. conflict intervention). Aby bylo možné tuto situaci odlišit od pouhého vytváření koalic, je nutné ukázat, že zasahující jedinec žádnému ze zúčastněných aktérů nestraní. Často se totiž intervenující jedinci přidávají na stranu svých příbuzných, což může vést naopak k eskalaci konfliktu. De Waal je přesvědčen, že u šimpanzů jsou někdy zásahy alfa samce vedeny snahou ukončit konflikt nezávisle na tom, jací jedinci se ho

\footnotetext{
${ }^{15}$ De Waal (2006a, s. 198).

${ }^{16}$ De Waal, van Roosmalen (1979, s. 62).

${ }^{17}$ Tamtéž, s. 62.

${ }^{18}$ De Waal (2006b, s. 35).
} 
zúčastňují. V této souvislosti je přesvědčivý případ, kdy se alfa samec Luit vrhl do klubka sváŕících se šimpanzů a trestal příslušníky obou stran do té doby, než se ve skupině obnovil klid. ${ }^{19}$

V př́ípadě zprostředkování a vměšování se zdá, že třetí strana jedná s ohledem na komunitu. Pro evoluci morálky je zásadní otázka, zdali jsou primáti schopni vnímat komunitu jako abstraktní entitu, o jejíž dobro se popřípadě starají. Ohled na komunitu (community concern) de Waal definuje jako ,zájem každého jedince na posilování těch charakteristik komunity či skupiny, které zvyšují prospěch vyplývající ze života ve skupině pro něj a jeho př́buzné“. ${ }^{20} \mathrm{~V}$ otázce intencionálního pojetí skupiny jejími (primátími) členy je třeba zohlednit, že ohled na komunitu je paralelní se zájmem jedince udržovat dobré vztahy s ostatními zvíraty, se kterými se neustále stýká. Každý se tak na snižování vnitřního napětí ve skupině přičiňuje vlastním dílem, přičemž výsledek je pozitivní pro celou skupinu: soudržnost skupiny je výhodná z hlediska její obživy i společné obrany. ${ }^{21}$

Další důležitou schopností, kterou můžeme najít u šimpanzů, je smysl pro sociální pořádek (sense of social regularity). De Waal používá následující definici:

„Smysl pro sociální pořádek je soustava očekávání o tom, jak se mnou (nebo ostatními) má být zacházeno a jak mají být rozdělovány zdroje. Kdykoli se skutečnost odchýlí od těchto očekávání k vlastní (nebo i cizí) nevýhodě, následuje negativní reakce, u podřazeného zvířete nejčastěji protest a u dominantního jedince potrestání provinilce. ${ }^{622}$

Smysl pro sociální pořádek je v zásadě egocentrický, někdy se ovšem týká i jiných zvírat, což de Waal zohlednil poukazy v závorkách. Předpokládá se přitom, že tento smysl je sdílen všemi individui ve skupině. Jedná se o analogii ke konsenzu o tom, co je dobře a špatně (consensual sense of right and wrong), který je podle Alexandera (1987), jak uvádí Flack a de Waal, základem recipročních systémů. ${ }^{23}$ Uplatňováním

${ }^{19}$ De Waal (1982, s. 124).

${ }^{20}$ de Waal (2006a, s. 251). Překladatel M. Špinka zvolil český termín „péče o komunitu“. $S$ přihlédnutím ke skutečnosti, že zde i jinde de Waal dává přednost neintencionálnímu pojetí komunity z pohledu jednotlivce, volíme raději „ohled na komunitu“. De Waalův výměr ohledu na komunitu je z normativního hlediska poněkud egocentrický. Propast mezi tímto evolučním stavebním kamenem morálky a morálkou lidskou se ovšem zmenší, jakmile si uvědomíme, jak sebestředně je založen koncept komunity v mysli typického partajního činovníka či řadového voliče.

${ }^{21}$ Flack \& de Waal (2000a, s. 15). Takto pojatý ohled na komunitu znamená v první řadě péči o zachování sociálního přediva, nikoliv normativní sledování pomyslného mravního kompasu.

${ }^{22}$ De Waal (2006a, s. 118).

${ }^{23}$ Flack \& de Waal (2000a, s. 4). 
tohoto smyslu dochází k takovému řešení konfliktů, které neohrožuje pořádek, na kterém je komunita založena. Zároveň se zdá, že jsou šimpanzi citliví na dodržování určitých „norem chování“, které přímo nesouvisejí s hierarchií uvnitř skupiny. ${ }^{24}$ Sociální pořádek může být narušen například odepřením pomoci jedinci, který ji dříve poskytl (narušení pravidel recipročního altruismu). ${ }^{25}$

Výše jsme uvedli řadu sociálních a kognitivních schopností, přítomných zejména u šimpanzů, které jsou nutnou prerekvizitou lidské morálky. De Waal mluví o stavebních kamenech morálky (building blocks of morality), mezi něž výslovně řadí reciprocitu a dělení se o potravu, usmiřování, utěšování, vměšování a zprostředkování. Tyto sociální dovednosti odrážejí skutečnost, že primáti jsou stejně jako člověk vybaveni schopností empatie, soucítění a v některých př́ípadech i ohledem na komunitu. V sentimentalistické teorii morálky je tato bazální úroveň nazývána mravními city (moral sentiments). ${ }^{26}$

V některých dalších dílech de Waal speciálně zmiňuje sociální tlak (social pressure) jako další stupeň morálky. ${ }^{27} \mathrm{Ve}$ fenoménech altruistického trestání a vměšování do konfliktu bylo popsáno, jak se další strana aktivně přičiňuje na obnovení sociálního pořádku. Důležitost této roviny v evoluci morálky ilustruje možnost, že bez této kontrolní role některých jedinců či skupiny jako celku by nad „mravními city“ mohly u některých jedinců postupně převážit asociální tendence.

Nejvyšší stupeň morálky je svázán se schopností soudu a rozvažování (judgment and reasoning). De Waal přisuzuje tuto schopnost v pravém smyslu pouze člověku. Lidská morálka je charakteristická potřebou zaujmout hledisko nestranného pozorovatele a vytvořit obecně platný systém hodnot. $\mathrm{K}$ tomu je potřeba rozvinutá abstrakce a sebereflexe, která umožní porovnávat vlastní motivace:

„Touha po vnitřně konzistentním morálním zarámování je jedinečně lidská. Jsme jediní, kdo se stará o to, proč si myslíme to, co si myslíme. Můžeme si například lámat hlavu, jak smířit náš postoj vůči potratům s postojem vůči trestu smrti, nebo za jakých okolností může být krádež ospravedlnitelná. Všechno toto je daleko abstraktnější než konkrétní stupeň chování, ve kterém se zdají jednat ostatní zvíŕata.“28

${ }^{24}$ De Waal (2006a, s. 120).

25 Smysl pro sociální pořádek je zejména u člověka spjat s internalizací pravidel a společenských norem. De Waal v tomto stupni evoluce morálky vidí základy lidského smyslu pro spravedlnost.

${ }^{26}$ Flack \& de Waal (2000a, s. 4).

${ }^{27}$ De Waal (2006c, s. 169).

${ }^{28}$ De Waal (2006c, s. 174). 


\section{Postavení de Waalovy teorie v rámci evoluční biologie}

De Waal svou verzi evoluční etiky buduje v dialektické opozici k teoriím $\mathrm{T}$. $\mathrm{H}$. Huxleyho, G. C. Williamse a R. Dawkinse. Všichni tito evoluční biologové kladli ostrou hranici mezi svět subhumánních tvorů, který podléhá pravidlům krutého přírodního výběru, a svět lidské kultury, kde je možné budovat morálku. Lidská biologická prrirozenost, která je prrímo odvozena od přirozenosti zvířecí, je v jádru egoistická a člověk se chová morálně jen zásluhou pečlivě udržované kulturní vrstvy. De Waal tento typ uvažování přezdil na „Veneer Theory“ (,teorie pozlátka“): lidská morálka je tenounkou vrstvou na přírodním jádru, které je zviŕecky sobecké a brutální.

Myšlenky vyrůstající z „Veneer Theory“ byly velmi populární v 70. - 80. letech 20. století. Neodarwinistický étos (především anglické provenience) spočíval ve snaze ukázat falešnost morálky tím, že nikdo z nás nemůže s vážnou tváří tvrdit, že jedná bez egoistických motivů. „Škrábni ,altruistu“ a dívej se, jak krvácí ,pokrytec““ - tak zní motto celé jedné generace výzkumníků chování. ${ }^{29} \mathrm{Už} \mathrm{v}$ případě mimo-lidských druhů bylo cílem dokázat, že zdánlivě altruistické chování má za skutečný cíl zvětšit vlastní zdatnost, fitness (v podobě šance na přežití, sociální postavení, vyhlídky na rozmnožení). Hezkým příkladem mohou být poplašné signály ptáků, které zbytek hejna varují před blížícím se predátorem. Tento na první pohled altruistický čin (signalizující pták může pozornost predátora zacílit na sebe) je vysvětlen tak, že aktivní jedinec zmanipuluje ostatní členy hejna $\mathrm{k}$ tomu, aby společně s ním odletěli do úkrytu. ${ }^{30}$

De Waal se rovněž jasně vymezuje proti sociobiologickému programu (především americké provenience). Samotného zakladatele sociobiologie E. O. Wilsona sice uznává jako jednoho z tvůrců programu evoluční etiky, na jeho postřehy o altruismu tvrdého a měkkého jádra však nenavazuje. ${ }^{31}$ Je to dáno tím, že holandský primatolog se nevěnuje testování hypotéz vycházejících z hamiltonovské teorie příbuzenského výběru (kin selection). Altruistické chování je podle něj spojeno se schopností soucítění (sympathy) a není funkcí prrímé úměry ke genetické příbuznosti. ${ }^{32}$ De Waal se zaměřuje na tzv. proximátní příčiny altruistického chování, které leží v psychické sféře člověka. (Tradiční sociobiologie podcenila význam emocí a kognitivního rozboru mysli s tím,

${ }^{29}$ Ghiselin (1974, s. 247). V anglickém originálu "Scratch an 'altruist', and watch a 'hypocrite' bleed".

${ }^{30}$ Srv. Dawkins (1998, s. 155-156).

${ }^{31}$ De Waal cituje Wilsonovu slavnou výzvu: „Přrišel čas, aby byla etika dočasně odebrána z rukou filosofu a byla biologizována.“ Wilson (1975, s. 562). Citováno v de Waal (2006c, s. 181), překlad F. J.

${ }^{32}$ De Waal (2006c, s. 164) nicméně uznává, že př́ijemcem altruistických aktů jsou u člověka v sestupné míře př́ibuzní jedinci, jedinci stejného klanu, národa, lidstva a člověku př́íbuzných druhů. 
jak se soustř̌edila převážně na hledání ultimátních evolučních příčin altruismu.) Soucítění je prritom výbavou již subhumánních tvorů a ve své fyziologické podstatě se mezi jednotlivými druhy savců téměř neliší. ${ }^{33} \mathrm{~V}$ této souvislosti si de Waal př́ípadně všímá, že přiznání altruistických motivací zvíratům bylo prakticky znemožněno slovníkem, se kterým se o nich v biologické komunitě smělo referovat:

„Laiky, kteří si představují biology jako prrírodní nadšence, může šokovat zjištění, že současná biologická literatura běžně vykresluje zvířata jako „hulváty“, „kořeny“ nebo „podvodníky“ jednající „,nenávistně“, „,nenasytně“ nebo „vražedně“. Není na nich nic milého! Když se zvířata chovají tolerantně a altruisticky, jsou tyto výrazy často umistovány do uvozovek, aby snad jejich autor nevypadal jako beznadějně romantický naivka. A když už se uvozovek zdá př́liš, používají se na označení pozitivních sklonů negativní nálepky. Např́iklad upřednostňování příbuzných, namísto aby bylo nazváno prostě „př́ibuzenskou láskou“, se někdy označuje jako „,nepotismus“، ‘34

De Waal výslovně poznamenává, že Darwinovi, nezpochybnitelnému zakladateli myšlenky evoluční etiky, byl černobílý styl myšlení typu „lidská přrirozenost je dobrá vs. je špatná“ bytostně cizí. ${ }^{35}$ Darwin se domníval, že vznik morálky je spojen s konfliktem instinktů, přičemž na jedné straně stojí individuální (egoistické) touhy a na druhé společenské instinkty, které jsou svou povahou trvalejší a výhodné pro druh jako celek. ${ }^{36}$ Morálka v plném slova smyslu je podle Darwina možná jen u člověka, nebot' ostatní živočichové postrádají intelekt vyvinutý do takové míry, aby byli s jeho pomocí schopni porovnávat důsledky předchozích rozhodnutí, což je základ svědomí (conscience).

De Waal stejně jako Darwin vychází z britské sentimentalistické teorie morálky. ${ }^{37}$ D. Hume a A. Smith byli přesvědčeni, že základem lidské morálky jsou mravní city (moral sentiments), z nichž nejdůležitější je schopnost soucítění (sympathy). Lidská morálka v plném smyslu však není možná bez koncepce dobra a zla a schopnosti nestranného zhodnocení situace. Sentimentalistickou tradici charakterizuje opozice

${ }^{33}$ De Waal fyziologický mechanismus soucítění, resp. empatie, odvozuje od tzv. percepčněakčního mechanismu. Blíže Preston \& de Waal (2002, s. 1-72).

${ }^{34}$ De Waal (2006a, s. 26-27).

${ }^{35}$ Flack \& de Waal (2000a, s. 20).

${ }^{36}$ Darwin (1982, s. 88). Darwinova teorie o původu morálky je velmi podobná de Waalově pohledu na emergenci morálního systému, který je uveden jako první výměr morálky v úvodu statě.

${ }^{37}$ Rozdíly mezi de Waalovou, Darwinovou a Smithovou koncepcí morálky jsou rozebrány ve stati van der Weele (2011, s. 583-593). 
k utilitarianistické teorii morálky, jejíž ozvěny v podobě kalkulací o šíření genetických kopií nalézáme v sociobiologickém pohledu na altruismus.

Ačkoliv se uvažování ve stylu „Veneer Theory“ v dnešní evoluční etice přežilo, její ozvuky v podobě kladení ostré hranice mezi svět zvířat a lidí nalezneme i u některých vlivných koncepcí. Peter J. Richerson a Robert Boyd se př́mo odvolávají na Darwinovu koncepci evoluční etiky, nicméně tvrdí, že anglický myslitel spatřoval mezi morálkou člověka a schopnostmi jiných tvorů obrovskou mezeru. V návaznosti na toto přesvědčení se zdráhají přiznat schopnost soucítění i zvířatům a Hamiltonovu teorii př́buzenské selekce označují za evoluční zákon gravitace (evolutionary law of gravity), ze kterého není úniku. V alegorii o mravenci argentinském (Linepithema humile) ukazují, že i když se zámořské (z pohledu Ameriky) kolonie tohoto druhu vyznačují neobyčejnou kooperativností, přesto jsou nakonec odsouzeny k válkám podle prríbuzenského systému. Člověk má však jako jediný tvor šanci se z této „evoluční hry“ osvobodit „posilováním neochvějného závazku k soucítění“ (the excercise of a steadfast commitment to sympathy). ${ }^{38}$

Styl de Waalova uvažování je v kontextu moderní biologické tradice dosti originální. Holandský badatel si je vědom toho, do jaké míry jsou naše teorie o přírodě ovlivněny kulturní a filosofickou tradicí. Na prvním místě máme kulturně daný obraz člověka, teprve poté modelujeme svět zvírrat prizmatem své kultury. Holandský badatel se vymezuje proti dualistickému myšlení, které vedlo k protěžování narativu egoismu proti altruismu v díle mnoha západních filosofů (Hobbes, Freud) a které stálo za vznikem „Veneer Theory“. De Waal upozorňuje, že člověk je celkem, ve kterém jsou obě polarity (příroda a kultura, egoismus a altruismus) sjednoceny. ${ }^{39}$ Aby vyvážil tradici poukazující na egoistickou povahu lidské přirozenosti, bere si de Waal na pomoc čínského konfuciánského myslitele Mencia. Podle Mencia existuje v člověku něco stejně instinktivního jako hlad a pohlavní pud: je to empatie, díky níž je pohled na utrpení bližního nesnesitelný. Čínský filosof př́imo tvrdí, že nemít smysl pro soucit není lidské. Schopnost rozlišovat, co je správné a co špatné, je pro něj jedním ze základních znaků lidské přirozenosti. ${ }^{40}$

\section{Christine M. Korsgaardová: kritika sentimentalistické teorie morálky}

Svou kritiku k převažující podobě evoluční etiky Korsgaardová předkládá v komentáři v knize Primates and Philosophers a dále ji rozpracovává v článku Reflections on the Evolution of Morality. Americká filosofka shledává problém v tom, že de Waal své

\footnotetext{
${ }^{38}$ Richerdson \& Boyd (2004, s. 72).

${ }^{39}$ De Waal (2006b, s. 10).

${ }^{40}$ Cheng (2006, s. 156). K Menciovu myšlení též Myšička (2014, s. 559-581).
} 
závěry odvozuje především z deskripce toho, jak se zvírata chovají. Následná interpretace jejich záměrů, zda jsou dobré či nikoli, dává dle jejího názoru smysl jen $\mathrm{v}$ rámci sentimentalistické tradice. $\mathrm{V}$ této tradici (Hume) je morálnost chování aktéra posuzována nikoliv podle jeho vlastního záměru, ale na základě hodnotitelovy interpretace. Aktér chování tak nemusí být sám motivován nějakou morální úvahou, kterou mu pozorovatel přisuzuje. ${ }^{41}$

Korsgaardová souhlasí s tím, že vyšší živočichové mají jistou úroveň intencionality. Jsou si vědomi svých záměrů a jejich jednání se dá považovat za úmyslné v tom smyslu, že směřuje k jejich dosažení. Korsgaardová však tvrdí, že záměry samotné jsou dány afektivními stavy, jakými jsou emoce a instinktivní nebo naučené touhy. ${ }^{42}$ Tento model zvírecího chování byl Harrym Frankfurtem charakterizován jako wanton: zviŕre si není schopné mezi afektivními stavy vybrat, chová se v souladu s nejsilnějším impulsem. ${ }^{43}$ Zviŕre nedokáže reflektivně zhodnotit své jednání, hlavním faktorem ovlivňujícím jeho afektivní stavy je okolní prostředí. Reprezentace vnějšího prostř̌edí pro zviŕre zahrnuje percepční informace, na které reaguje touhou po něčem nebo vyhýbání se něčemu. Percepce zvírete má tedy teleologický obsah. Vnímá věci kolem sebe jako „věc, před kterou by měl utéct“ či „věc, která je určena k snědku“. Předměty, které vnímá, tak považuje za vhodné „pro“ nějakou reakci. Racionální živočich má však nejen takovýto stupeň vědomí, který ovládá jeho činnost, ale již vyvinuté sebeuvědomění, skrze které dokáže vnímat, že se něčeho bojí nebo že po něčem touží (reflektivita). ${ }^{44}$

Korsgaardová soudí, že lidé mají intencionalitu na daleko vyšší úrovni než jakýkoliv druh živočichů. Naše cíle mohou být taktéž určeny afektivními stavy, nicméně jsme připraveni je odmítnout, pokud soudíme, že by bylo špatné je následovat. Nevybíráme si totiž jenom prostředky, nýbrž také cíle samotné. ${ }^{45}$ Klíčovým pojmem pro Korsgaardové pojetí deontologické etiky je sebeuvědomění, které nám dává možnost přemýšlet o strachu či touhách, které pocit’ujeme. Jsme si vědomi svých postojů. Tím získáváme jistou reflexivní vzdálenost od motivů našich činů a jsme již ve fázi, kdy se sami sebe ptáme, zda je správné se chovat tímto a ne jiným způsobem. A právě v tuto chvíli se člověk nachází v pozici, kdy si klade normativní otázky po tom, co by měl činit. Korsgaardová se domnívá, že zdrojem této formy sebeuvědomění je rozum. Rozum však odděluje od inteligence. Zatímco inteligence je schopností učit se nové

\footnotetext{
${ }^{41}$ Korsgaard (2006, s. 106).

42 Tamtéž, s. 110.

${ }^{43}$ Frankfurt (1971, s. 11-15).

${ }^{44}$ Korsgaard (2010, s. 21).

${ }^{45}$ Korsgaard (2006, s. 112).
} 
skutečnosti o světě, aplikovat své zkušenosti na nové př́ípady a používat tyto znalosti ve vztahu k účelu, rozum je naopak zaměřen dovnitř, na afektivní stavy. ${ }^{46}$

Korsgaardová tak nesouhlasí s de Waalem, že základy morálky můžeme najít u našich evolučně blízkých lidoopů. Morálnost chování je funkcí uplatnění normativní autonomie (normative self-government), této formy sebeuvědomění však zvíře nemůže dosáhnout. ${ }^{47}$ Lidský morální rámec je z hloubi normativní, zatímco zvířecí nikoli. I velice inteligentní zviŕata se rrídí instinkty, touhami a emocemi, zatímco pro lidskou formu života je charakteristické, že se řídí pravidly a hodnotami. Lidské chování je charakterizováno představami o tom, jak bychom měli jednat, zatímco zvîre, které nazveme nap̌r. „statečným“, se tak nechová proto, že by „mělo“. Morálka dává lidským jedincům zcela jiný způsob bytí ve světě. ${ }^{48}$

\section{Mary Midgleyová: místo rozumu mezi city}

Dlouhověká anglická filosofka Mary Midgleyová dlouhodobě nesouhlasí se způsobem, jak se o zvířeti uvažuje v rámci neodarwinistického paradigmatu. Ve druhé polovině 70. let vydává knihu Beast and Man: The Roots of Human Nature, kde se vyrovnává se západní tradicí myšlení o vztahu člověka a zvírete a komentuje její tehdy novou podobu, Wilsonův program sociobiologie. O třicet let později ve své skvěle napsané knize The Solitary Self: Darwin and the Selfish Gene demaskuje jednostrannost logiky teorie sobeckého genu a přesvědčivě ukazuje, že tento proud neodarwinistického výzkumu morálky je na hony vzdálen Darwinovu uvažování.

Podle Midgleyové je naše přirozenost výsostně společenská a její součástí jsou hluboké náklonnosti (affections) k ostatním lidem. Ideál racionálního člověka, který se rozumově rozhoduje v souladu se svými egoistickými zájmy, vzývaný zejména v moderní ekonomii, je zpochybněn odkazem na svou živou inkarnaci, kterou bychom nazvali asociálním psychopatem. ${ }^{49}$

Podle Midgleyové tak morálka nespočívá primárně v naší rozumové schopnosti, ale vyvstává z obtížnosti sladit intelekt s již existujícími sociálními city. Samotná inteligence je pak vývojově odvozena od nutnosti orientace ve složité vztahové spleti primátí tlupy, nikoliv od nutnosti řešit problémy spojené s výrobou nástrojů apod. ${ }^{50}$ Midgleyová se ohrazuje proti platónské vizi rozumu jako vozataje, který drží na uzdě

\footnotetext{
${ }^{46}$ Korsgaard (2010, s. 24).

${ }^{47}$ Korsgaard (2006, s. 112).

${ }^{48}$ Tamtéž, s. 117.

${ }^{49}$ Midgley (2010, s. 61).

${ }^{50}$ Tamtéž, s. 27-28. Viz též Midgley (2002, s. 265).
} 
vzpínající se koně emocí. S ohledem na evoluční chápání vývoje lidských kognitivních schopností (vzpomeňme de Waalovu „bottom-up perspective“) musí rozum vyrůstat ze stejného kmene jako city a touhy. To vede filozofku k reflexi samotného významu slova „rozumnost“: spíše než na sílu čistého racia se v běžném životě při poukazu na rozumnost odvoláváme na spojení praktických schopností a emočně relevantní orientace v situaci. ${ }^{51}$ Rozumnost je technikou umožňující sladit protichůdné city.

Midgleyová nepředstavuje vyhraněnou pozici k problému evolučního vzniku etiky, rozhodně ne v tom smyslu, že by se snažila určit moment, který člověka učinil morální bytostí. V zásadě se shoduje s Darwinovým pohledem na původ morálky jako opozice mezi sociálními instinkty a individuálním zájmem. Specifickým rysem člověka je jeho schopnost kritické sebereflexe, která způsobuje, že city jím prožívané se odlišují od jejich před-reflektivních případů. To ovšem neznamená, že by lidské city představovaly kvalitativně odlišný soubor motivací. Evoluční kontinuita navíc nechává alespoň teoretickou možnost, že reflexe vlastních činů jsou schopna i zvírata. ${ }^{52}$

Svědomí patří k lidské přirozenosti, ovšem ne $\mathrm{v}$ tom smyslu, že by překonávalo naše biologické danosti, ale že je prostorem reflexe toho, jak naše přirozenost vypadá. Rovněž chování zviŕrete se odvíjí od přirozenosti jeho vlastního druhu a výrazné odchylky od sociální normy druhu musí být hodnoceny jako špatné. ${ }^{53}$ U vysoce sociálních druhů (např. vlků) hluboká náklonnost převažuje nad chvilkovými impulsy a touhami. Při protichůdných motivech je zvírre nuceno si vybrat a podle jeho rozhodnutí se určuje, kým se ve své skupině pro ostatní stává. V protikladu k přirovnání k ,wantons“ u Korsgaardové zviŕre má vládu nad svým chováním, na rozdíl od člověka však problém rozhodování není řešen tím, že by využívalo teoretický rozum a složitě reflektovalo možné scénáře.

\section{Závěr}

Představili jsme postupně čtyři př́istupy k evoluční etice: anti-esencialistickou pozici de Waala, tzv. Veneer Theory postulující silnou dichotomii prírody a kultury, deontologický pohled Korsgaardové a přístup Midgleyové, který leží na pomezí sentimentalismu a etiky ctností. Kdybychom měli schematicky znázornit rozdíly a podobnosti zmiňovaných pozic, jednou z možností je následující tabulka. ${ }^{54}$ Zatímco rozdělení do sloupců nepotřebuje žádný bližší komentář, řádková kategorizace může působit překvapivě. Dawkinsův Sobecký gen (exemplární případ myšlení ve stylu

\footnotetext{
${ }^{51}$ Tamtéž, s. 70.

${ }^{52}$ Tamtéž, s. 81.

${ }^{53}$ Midgley (2002, s. 263-269).

${ }^{54}$ Za upozornění na možnost takového zachycení vděčíme Marku Špinkovi.
} 
Veener Theory) se do obecného povědomí zapsal jako dílo, které má vysvětlit chování zviŕat a člověka univerzálním teoretickým aparátem. Ve skutečnosti se však závěrečným obrazem vzpoury člověka proti tyranii sobeckých replikátorů vymezuje proti determinismu a navazuje na osvícenský ideál člověka jako bytosti rozumu. ${ }^{55}$ Esencí morálky je zde altruismus a člověk je jedinou bytostí, která může svůj altruismus posilovat rozumem. Na význam rozumu pro morální konání explicitně upozorňuje i Korsgaardová, která možnost morálky vůbec odvozuje od schopnosti normativní autonomie. V kontrastu k těmto pohledům, které lze považovat za esencialistické, podávají de Waal a Midgleyová evoluční popis morálky jako souboru schopností, které mají vícečetné zdroje. Ačkoliv i zde najdeme mezi charakteristikami morálního konání člověka rozumovou reflexi, kontinuita zvírete a člověka je zdůrazněna dvojím způsobem: zaprvé poukazem na primární význam empatie pro evoluci morálky, zadruhé přesvědčením o stejné povaze rozumu zvíratat a lidí.

\begin{tabular}{|c|c|c|}
\hline $\begin{array}{c}\text { Teorie morálky (řádky) / } \\
\text { Způsob jejího zkoumání } \\
\text { (sloupce) }\end{array}$ & Biologická teorie a empirie & Filozofická reflexe \\
\hline Esencialismus & Veneer Theory & Korsgaardová \\
\hline Anti-esencialismus & de Waal & Midgleyová \\
\hline
\end{tabular}

V díle Midgleyové se dále odráží přesvědčení, že morální myšlení u člověka vyvstává z potřeby překlenutí konfliktů mezi soupeřícími emocemi, touhami a rozumem. Perspektivou je jednota celku, vyváženost lidského individua. ${ }^{56} \mathrm{~V}$ tomto přístupu se stírá rozdíl mezi evolučním a normativním přístupem: darwinovská teorie o původu morálky ze soupeření individuálních a sociálních ohledů se mísí s morálním poukazem na potřebu sjednocení vlastní osoby jakožto celku, ve kterém se řečené konflikty odehrávají. Odrazem této celosti jsou nejrůznější podoby chování, kterým se člověk projevuje: nenajdeme jedince, v jehož činech by se egoistické a altruistické motivy složitě nezrcadlily. Podobně se de Waal snaží představit naše evoluční př́buzné jako zvîrata, která nejsou primárně ani altruistická, ani egoistická.

Kantovský výměr etiky, ze kterého vychází Korsgaardová, se jen úzce překrývá s tím, co morálkou nazývá de Waal. Abstraktní normativní přístup je vhodný spíše jako základ právních norem a soudnictví než pro (mravní) orientaci, jak zvládat každodenní napětí ve vztazích mezi lidmi. Je dobré si uvědomit, že důsledné uplatňování kantovské podoby etiky by v situacích jako výchova dítěte vedlo k citové deprivaci: zde se ukazuje

\footnotetext{
55 Jaroš (2015).

56 Tamtéž, s. 80. Kantovská etika se svým negováním významu emocí při morálním rozhodování je krystalickým př́kladem uvažování, kde rozumové a afektivní složky osoby nejsou uvedeny v soulad.
} 
důležitost mravních citů pro náš zdravý morální vývoj. ${ }^{57} \mathrm{Z}$ perspektivy evoluční etiky de Waala se Korsgaardové pojetí morálky zdá být extenzí smyslu pro sociální pořádek (zde dochází během evoluce k internalizaci norem). Její deontologický výměr naopak prakticky nezahrnuje tišení konfliktů a ohled na komunitu.

Korsgaardová uznává evoluční původ morálky, ale ukazuje, že jde o natolik složitý fenomén, že k jeho postihnutí potřebujeme jiné než biologické prostředky. Lidská forma života je odlišná od života ostatních lidoopů natolik, že její původ můžeme vysvětlit pouze skokovou změnou. ${ }^{58} \mathrm{~V}$ rámci evoluční teorie bychom řekli, že morálka je specifickou lidskou adaptací, evoluční novinkou zrozenou v pleistocénu. Takovým krokem učiníme zadost „taxonomickému“ oddělení člověka od ostatních živočichů. Nemusíme se dále zabývat nepohodlnou otázkou, zda jsou šimpanzi schopni pocit'ovat dobro a zlo, činit normativní soudy apod. Na druhou stranu se vzdalujeme darwinistickému přístupu k evoluční problematice, který si klade za cíl vysvětlit vznik evolučních novinek sérií postupných změn. Současné evoluční myšlení málo uspokojí teze, že lidská morálka vznikla skokem ze systému řízení konfliktů v tlupách šimpanzů.

Nesourodost sentimentalistického a deontologického etického rozvrhu nepřímo reflektuje de Waal, když svůj př́stup, založený na sentimentalismu, popisuje jako odvozování vyššího z nižšího (bottom-up perspective). Na druhou stranu máme normativní př́stup, který morálnost jednání posuzuje z hlediska obecně závazné maximy (top-down perspective). De Waal do svého rozvrhu zahrnuje i význam rozumu a reflexivní schopnost člověka nakonec považuje za nejvyšší stupeň morálky (pravděpodobně $\mathrm{v}$ reakci na zmíněné kritiky), odmítá však odvozovat morálnost chování výhradně od vysokých kognitivních schopností. Na tomto místě přichází za účelem vyjasnění své pozice s metaforou „věže morálky“ (tower of morality). V základech stavby morálních systémů jsou mravní city, další stupeň tvoří společenský tlak a nejvyšší patro je obsazeno schopností soudu a rozvažování. ${ }^{59}$

Metafora věže morálky je příhodným anti-esencialistickým obrazem evoluce mravnosti. Evoluční etika ze své podstaty musí exponovat takové oblasti morálky, jejichž analogie je potenciálně možné najít u zvířat. Tato metodická redukce ovšem nevylučuje charakterizaci vlastností nebo typů chování, které u mimo-lidských tvorů nejsme schopni (zatím?) vystopovat. De Waal zde uvádí reflexivní schopnost soudu a rozvažování (judgment and reasoning) a touhy po konzistentním morálním kompasu, která je jedinečně lidská. Zde se sice přibližuje stanovisku Korsgaardové, ovšem

\footnotetext{
${ }^{57}$ Viz též Waller (1997, s. 341-356).

${ }^{58}$ Korsgaard (2006, s. 117).

${ }^{59}$ De Waal (2006c, s. 167-175).
} 
nalezení základů morálky u zvířat není tímto stanoviskem vyloučeno per definitionem. ${ }^{60}$ Podle de Waala navíc není možné zaměřit pohled pouze na nejvyšší patro věže morálky, protože při narušení jejích spodních pater (mravní city) se celá stavba zřítí.

Kromě rozdílných pohledů na morální teorii odlišuje de Waala a Korsgaardovou jejich rozdílné hodnocení zvírrecích schopností. Australský psycholog Thomas Suddendorf upozorňuje, že jakékoliv zviŕrecí chování lze interpretovat jako komplexní a v podstatě podobné lidskému (rich explanation), nebo naopak jako výsledek jednoduchého procesu učení (lean explanation). Mezi těmito perspektivami nelze objektivně rozhodnout a různí vědci (často podle svých osobních psychických preferencí) upřednostňují různé přístupy. ${ }^{61}$ Vyjdeme-li ze Suddendorfova dělení, de Waal se jednoznačně přiklání k „bohatému“ způsobu vysvětlování. Na druhé straně Korsgaardová přrirovnává subhumánní zvířata k „,wantons“, která se náhodně přiklání $\mathrm{k}$ instinktu, který je $\mathrm{v}$ danou chvíli nejsilnější. V otázce jejich schopnosti reflektovat vlastní chování je skeptická, pro „bohatý“ způsob vysvětlování nevidí opodstatnění.

Ačkoliv Korsgaardová souhlasí s postulátem evoluční etiky, její definice morálky neumožňuje plodný empirický výzkum v tomto oboru. Můžeme souhlasit, že funkcí normativní autonomie disponuje pouze člověk, nemáme však návod, jak analogii této funkce zkoumat u zvírat. Pro de Waala je evoluce morálky spojitým procesem, Korsgaardová se zdá stále zachovávat dichotomii „instinktivní zvíře“ - „morální člověk“. Je ovšem příznačné, že empirickou metodou je nemožné existenci normativní autonomie dokázat rovněž u konkrétních lidí. Nejen zviŕrata, ale rovněž mnozí naši spoluobčané se mohou ukazovat jako „wantons“, stvoření, která ve svém jednání spíše odpovídají na momentální hnutí duše, místo aby sledovala morální cíle.

${ }^{60} \mathrm{Na}$ tomto místě lze namítnout, že rovněž u lidí je těžké z vnějších znaků chování př́ímo usoudit na schopnost soudu či rozvažování. Tuto dovednost přiřazujeme ostatním lidem na základě jejich řečových projevů a v posledku skrze analogii $\mathrm{s}$ naším vlastním vnitřním rozpoložením. Existuje nicméně behaviorální projev řečených schopností: instituce rozhodčího sporu nebo rovnou soudu. Zatímco nějakého nestranného rozhodce šimpanzích půtek si lze v principu představit (vzpomeňme šimpanzího samce Luita), jediným behaviorálním projevem schopnosti normativní autonomie je přednáška či písemnost v kantiánské tradici. Obecně lze shrnout, že filozofické reflexe vztahující se k vymezení morálky budou pro zkoumání základů morálky u zviŕrat př́nosné do té míry, nakolik budou důkladně znalé současného stavu empirických biologických poznatků, popřípadě schopné precizovat formulaci zde řešených problémů a uvádět realistické př́íklady.

${ }^{61}$ Viz Suddendorf (2013). 


\section{Poděkování}

Poděkování patří kolegům z KFSV FF UHK a dvěma recenzentům za cenné připomínky. Článek vznikl za podpory projektu specifického výzkumu na Univerzitě Hradec Králové.

\section{Literatura}

Alexander, R. D. (1987): The Biology of Moral Systems. Aldine de Gruyter, New York. Darwin, Ch. (1982): The Descent of Man, and Selection in Relation to Sex. Princeton University Press, Princeton.

Dawkins, R. (1998): Sobecký gen. Mladá fronta, Praha.

De Waal, F. (1982): Chimpanzee Politics: Power and Sex Among Apes. Jonathan Cape, London.

De Waal, F. (2006a): Dobráci od přírody. Academia, Praha.

De Waal, F. (2006b): „Morally Evolved.“ In Primates and Philosophers: How Morality Evolved, eds. S. Macedo \& J. Ober, Princeton University Press, Princeton, 2006, s. $1-80$.

De Waal, F. (2006c): „The Tower of Morality.“ In Primates and Philosophers: How Morality Evolved, eds. S. Macedo \& J. Ober, Princeton University Press, Princeton, 2006, s. 161-182.

De Waal, F. (2011): The Age of Empathy. Nature's Lessons for a Kinder Society. Souvenir Press, London.

De Waal, F. \& Van Roosmalen, A. (1979): „Reconciliation and Consolation Among Chimpanzees." Behavioural Ecology and Sociobiology 5 (1): 55-66.

Flack, J. C. \& De Waal, F. (2000a): „,Any Animal Whatever“: Darwinian Building Blocks of Morality in Monkeys and Apes." In Evolutionary Origins of Morality: Cross - Disciplinary perspectives, ed. L. D. Katz, Imprint Academic, Thorverton, 2000, s. 1-30.

Flack, J. C. \& De Waal, F. (2000b): „Being Nice Is Not a Building Block of Morality.“ In Evolutionary Origins of Morality: Cross - Disciplinary perspectives, ed. L. D. Katz, Imprint Academic, Thorverton, 2000, s. 67-77.

Frankfurt, H. G. (1971): „Freedom of the Will and the Concept of Person.“ The Journal of Philosophy 68 (1): 11-15.

Ghiselin, M. (1974): The Economy of Nature and the Evolution of Sex. University of California Press, Berkeley.

Cheng, A. (2006): Dějiny čínského myšlení. DharmaGaia, Praha. 
Jaroš, F. (2015): „Zvîre jako člověk, zvírre jako stroj.“ Filosofický časopis 63 (4): 519537.

Korsgaard, Ch. M. (2006): „Morality and the Distinctiveness of Human Action.“ In Primates and Philosophers: How Morality Evolved, eds. S. Macedo \& J. Ober, Princeton University Press, Princeton, 2006, s. 98-119.

Korsgaard, Ch. M. (2010): „Reflections on the Evolution of Morality.“ The Amherst Lecture in Philosophy 5: 1-29. [online] (Cit. 11. 12. 2014) Dostupné z: $<$ http://www.amherstlecture.org/korsgaard2010/> .

Midgley, M. (1991): „The Origin of Ethics.“ In A Companion to Ethics, ed. P. Singer, Blackwell, Oxford, 1991, s. 3-13.

Midgley, M. (2002): Beast and Man. The Roots of Human Nature. Routledge, London and New York.

Midgley, M. (2010): The Solitary Self: Darwin and the Selfish Gene. Acumen, Durham.

Myšička, S. (2014): „Mencius o lidské přirozenosti a vládě lidskosti.“ Filosofický časopis 62 (4): 559-581.

Preston, S. D. \& De Waal, F. (2002): „Empathy: Its ultimate and proximate bases.“ Behavioral and Brain Sciences 25 (1): 1-72.

Provine, R. R. (2000): Laughter: A Scientific Investigation. Penguin Group, New York.

Richerson, P. J. \& Boyd, R. (2004): „Darwinian Evolutionary Ethics: Between Patriotism and Sympathy." In Evolutionary Ethics: Biological and Theological Perspectives on Human Morality, eds. P. Clayton \& J. Schloss, Wm. B. Eerdmans Publishing Co, Michigan, 2004, s. 50-73.

Suddendorf, T. (2013): The Gap: The Science of What Separates Us from Other Animals. Basic Books, New York.

Trivers, R. L. (1971): „The Evolution of Reciprocal Altruism.“ The Quarterly Review of Biology 46 (1): 35-57.

Van der Weele, C. (2011): „Empathy's Purity, Sympathy's Complexities; De Waal, Darwin and Adam Smith." Biology \& Philosophy 26 (4): 583-593.

Waller, B. N. (1997): „What Rationality Adds to Animal Morality.“ Biology \& Philosophy 12 (3): 341-356.

Wilson, E. O. (1975): Sociobiology: The New Synthesis. Harvard University Press, Cambridge, MA. 